\title{
RA?EGA
}

O ESPACYO GEOGRÁFICO EM ANÁLISE

\section{ANÁLISE CARTOGRÁFICA DAS ALTERAÇÕES DAS FEIÇÕES GEOMORFOLÓGICAS DECORRENTES DA OCUPAÇÃO DA ILHA COMPRIDA/SP ENTRE 1962 E 2012}

\section{CARTOGRAPHIC ANALYSIS OF THE GEOMORPHOLOGICAL FEATURES RESULTING FROM THE OCCUPATION OF ILHA COMPRIDA/SP BETWEEN 1962 AND 2012}

\author{
Tissiana de Almeida de Souza \\ Programa de Pós-Graduação em Geografia - Instituto de Geociências \\ Universidade Estadual de Campinas (UNICAMP) \\ Campinas, $S P$ \\ e-mail: tissisouza@yahoo.com.br \\ Regina Célia de Oliveira \\ Departamento de Geografia - Instituto de Geociências \\ Universidade Estadual de Campinas (UNICAMP) \\ Campinas, $S P$ \\ e-mail: reginacoliveira@ige.unicamp.br
}

Recebido em: 19/11/2014

\section{Resumo}

As áreas litorâneas são consideradas sistemas de elevada complexidade ambiental, relacionada aos fatores atuantes em sua formação, como as dinâmicas oceanográfica, fluvial, climática, geológica, geomorfológica e, atualmente, a ação antrópica. A evolução destas regiões pode ser mais bem compreendida a partir do uso da Cartografia Geomorfológica, já que os procedimentos de elaboração de mapas detalhados do relevo buscam inter-relacionar as formas, seus processos morfogenéticos e sua cronologia. Assim, este trabalho tem como objetivo analisar e discutir as alterações do relevo no município de Ilha Comprida, a partir de cartas geomorfológicas de detalhe elaboradas em séries temporais (1962, 1981 e 2011 2012), na escala original 1:10.000. Apesar da intensa especulação imobiliária, a Ilha Comprida ainda apresenta formas de relevo bem preservadas. O cenário de 1962 é marcado pela conservação de características naturais, enquanto nos cenários de 1981 e de 2011-2012 são observadas alterações das feições geomorfológicas por influência das atividades humanas. As principais modificações observadas são o fracionamento de cordões litorâneos e a alteração de áreas de dunas. Desta maneira, a utilização de cartas geomorfológicas na área de estudo pode contribuir no planejamento urbano e direcionamento da ocupação humana, bem como fornecer subsídios para a determinação de zonas de expansão urbana e de proteção às propriedades naturais da área de estudo. 


\section{ANÁLISE CARTOGRÁFICA DAS ALTERAÇÕES DAS FEIÇÕES GEOMORFOLÓGICAS DECORRENTES DA OCUPAÇÃO DA ILHA COMPRIDA/SP ENTRE 1962 E 2012}

Palavras-chave: Cartografia Geomorfológica, Formas de relevo costeiro, Especulação Imobiliária, Crescimento Urbano.

\section{Abstract}

The coastal areas are considered systems of high environmental complexity due to the factors acting on their formation, such as the oceans, fluvial, climatic, geological, and geomorphological dynamics and, more recently, the anthropic action. The evolution of these regions can be better understood through the use of the Geomorphological Mapping, once the procedures to elaborate detailed maps crossrelate the forms, the morphogenetic processes and their chronology as well. Thus, this study aims to analyze and discuss the relief alterations in the municipality of Ilha Comprida through geomorphological mapping elaborated in time series (1962, 1981 and 2011-2012), in the original scale 1:10.000. Despite the intense real state speculation, Ilha Comprida still presents a well preserved relief. The scenario of 1962 is marked by the conservation of the natural characteristics, while in 1981 and 20112012 alterations in the geomorphological features resulting from human activity are observed. The main alterations are the beach ridges fractionation and modification of the dunes area. Therefore, the use of geomorphological mapping in the area might contribute for a better urban planning, directing the human occupation and provide subsidies to determine the urban expansion zones while ensuring the protection of the natural properties of the study area.

Keywords: Geomorphological Mapping, Coastal relief forms, real state speculation, urban growth.

\section{INTRODUÇÃO}

O entendimento da dinâmica geomorfológica é fator de grande importância na análise da paisagem, já que, como afirma Casseti (1991, p.34), "o relevo, como componente desse estrato geográfico no qual vive o homem, constitui-se em suporte das interações naturais e sociais". Mais que o resultado da ação de forças exógenas e endógenas, é sobre o relevo "[...] que se reflete o jogo das interações naturais e sociais".

Segundo Girão; Corrêa (2004, p.36), o relevo é um elemento natural que teve grande influência no desenvolvimento das civilizações humanas, pois as feições geomorfológicas determinaram a ocupação e o incremento de atividades agrícolas, como por exemplo, nas planícies de inundação dos rios Tigre e Eufrates, na antiga Mesopotâmia. De acordo com Girão; Corrêa (2004, p.37), as características geomorfológicas influenciam os tipos de uso do solo, seja em áreas urbanas ou 


\section{ANÁLISE CARTOGRÁFICA DAS ALTERAÇÕES DAS FEIÇÕES GEOMORFOLÓGICAS DECORRENTES DA OCUPAÇÃO DA ILHA COMPRIDA/SP ENTRE 1962 E 2012}

rurais, a exploração de recursos naturais, o desenvolvimento de obras viárias, a utilização do espaço para lazer e turismo.

Quando se trata do litoral, a ilusória simplicidade paisagística disfarça uma complexidade de elementos atuantes em sua configuração, como alterações do nível do mar e variações paleo-climáticas. Assim, as regiões litorâneas exigem considerações semelhantes ou até mesmo mais complexas que as áreas localizadas no interior dos continentes (AB'SABER, 2000, p.27). Neste sentido, o posicionamento geográfico do litoral, em uma zona de interface entre oceano e continente, permite a atuação de processos distintos, como a dinâmica oceanográfica, fluvial, climática, geológica e geomorfológica. A estes processos naturais somam-se as ações antrópicas, que alteram as formas de relevo e tipos vegetacionais únicos, como manguezais e restingas.

Segundo Souza; Oliveira (2012a, p.01), a dinâmica das áreas litorâneas pode ser mais bem compreendida a partir da utilização da Cartografia Geomorfológica, já que os procedimentos de elaboração de mapas detalhados do relevo buscam relacionar as feições geomorfológicas com seus processos morfogenéticos e a cronologia do embasamento. Cunha et al. (2003, p.01) afirmam que esta relação forma-processo-cronologia torna-se mais bem compreendida quando se encontra espacializada em documentos cartográficos.

Conforme Guerra; Marçal (2006, p.66), o conhecimento em Geomorfologia poderia contribuir com o planejamento da ocupação de áreas litorâneas e evitar uma série de problemas ambientais, como erosão costeira, destruição de manguezais, saneamento e poluição.

Com base nas considerações apresentadas, este trabalho tem como objetivo analisar e discutir as alterações do relevo no município de Ilha Comprida, localizado no litoral Sul do estado de São Paulo, a partir de cartas geomorfológicas de detalhe elaboradas em séries temporais, em escala original 1:10.000. Para a elaboração dos produtos cartográficos, foram utilizados pares estereoscópicos de fotografias aéreas para os cenários de 1962 e 1981 e imagens de alta resolução para o cenário de 2011-2012. Para uma apreciação em que se possam observar as modificações do relevo ocorridas na área de estudo com maior detalhamento, optou-se pela seleção 


\section{ANÁLISE CARTOGRÁFICA DAS ALTERAÇÕES DAS FEIÇÕES GEOMORFOLÓGICAS DECORRENTES DA OCUPAÇÃO DA ILHA COMPRIDA/SP ENTRE 1962 E 2012}

de fragmentos representativos das cartas geomorfológicas correspondentes aos cenários utilizados.

A análise será realizada com base na Abordagem Sistêmica aplicada à Geomorfologia, considerando-se a área, DE acordo com o critério de funcionalidade (CHORLEY; KENNEDY, 1971, citados por CHRISTOFOLETTI, 1999, p.06), como um sistema aberto, no qual ao modificar um de seus elementos, todo o sistema sofrerá alteração. Neste contexto, incluem-se as ações antrópicas, que podem ocorrer livremente, pois o sistema recebe matéria e energia de qualquer agente externo. Considerando-se o critério de complexidade estrutural a área de estudo é considerada sistema de processos-respostas, pois apresenta diversas feições geomorfológicas preservadas, o que permite realizar a associação aos seus processos geradores. A área de estudo pode ser considerada também como um sistema controlado, no qual a intervenção do Homem altera os processos, através da modificação dos fluxos de matéria e de energia e promove uma nova dinâmica nos sistemas morfológicos. A interferência antrópica pode se dar, por exemplo, através da urbanização, que altera a topografia e o escoamento pluvial e fluvial.

A Ilha Comprida apresenta uma área territorial municipal de $191,9 \mathrm{~km}^{2}$ (INSTITUTO BRASILEIRO DE GEOGRAFIA E ESTATÍSTICA - IBGE, 2014), com extensão longitudinal de cerca de $70 \mathrm{~km}$, e largura variante entre a margem oceânica e a margem lagunar entre $500 \mathrm{~m}$ e $5 \mathrm{~km}$.

A ilha está isolada da área continental pelo canal lagunar do "Mar Pequeno" ou "Mar de Iguape", em sentido Nordeste. Na direção Sudoeste, a ilha encontra-se separada da Ilha de Cananeia pelo canal do "Mar de Cananéia" ou "Mar de Fora". A Figura 1 mostra a localização da área de estudo.

Conforme Martin; Suguio (1978, p.908-909), o processo de gênese e evolução da llha Comprida está associado a flutuações do nível do mar ao longo do Quaternário, com a seguinte sequência:

- O trecho Sudoeste da ilha formou-se a partir da deposição de sedimentos durante a Penúltima Transgressão, também chamada de Transgressão Cananeia, ocorrida há aproximadamente 120.000 anos A.P. (Antes do Presente), constituindo a Formação Cananeia; 


\section{ANÁLISE CARTOGRÁFICA DAS ALTERAÇÕES DAS FEIÇÕES GEOMORFOLÓGICAS DECORRENTES DA OCUPAÇÃO DA ILHHA COMPRIDA/SP ENTRE 1962 E 2012}

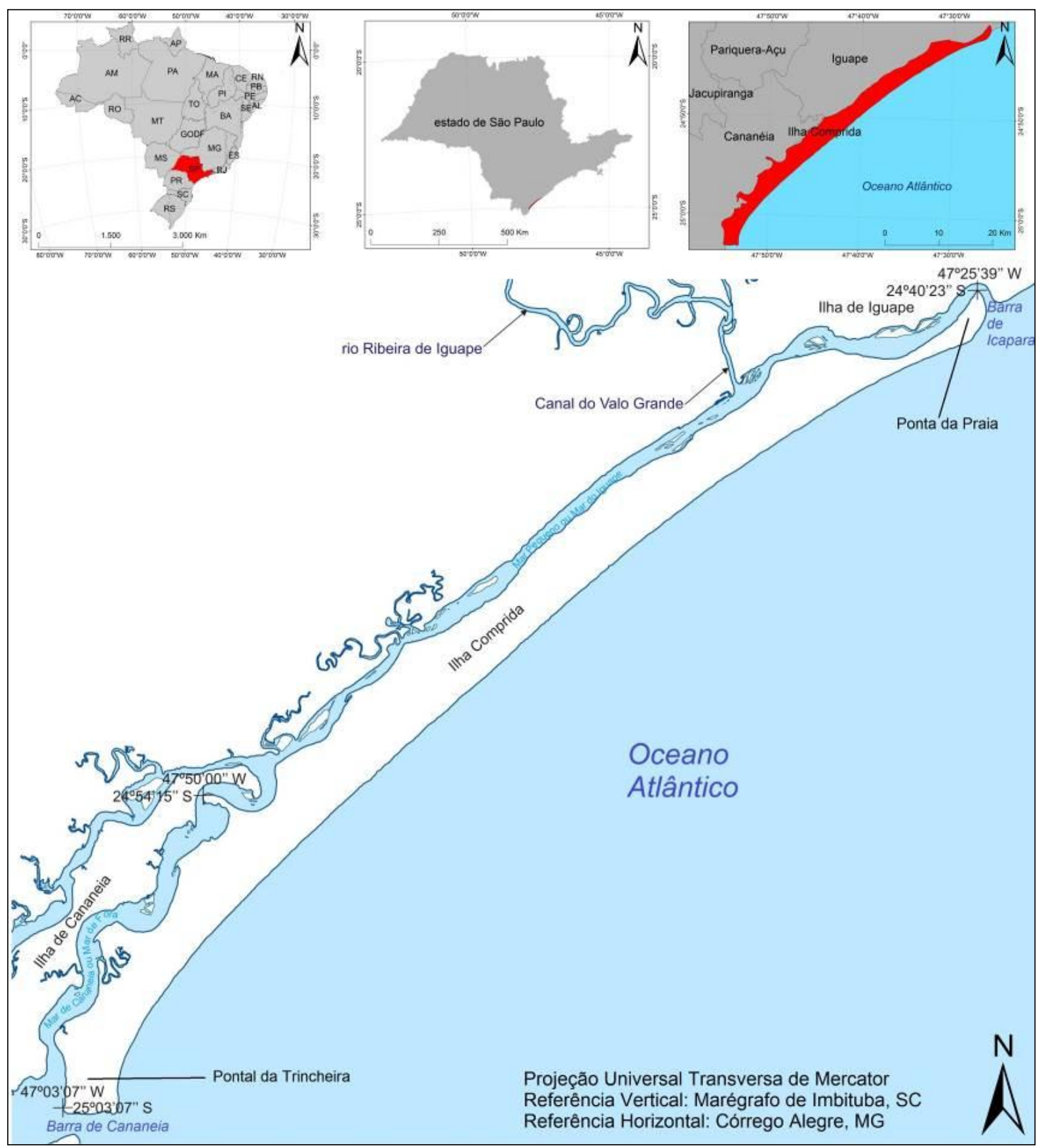

Figura 1: Localização geográfica da área de estudo.

Fonte: Adaptado de IBGE $(1973,2000)$.

Organização das autoras (2014).

- Ao longo da Última Transgressão (Transgressão Santos), flutuações do nível do mar provocaram a erosão e o rebaixamento de parte da Formação Cananeia;

- No máximo da Última Transgressão, quando o mar esteve cerca de 3 metros acima do nível atual, formou-se uma "ilha primitiva";

- Em novo período de regressão marinha, constituíram-se cordões litorâneos em sentido Nordeste, promovendo o crescimento longitudinal da ilha. 


\section{ANÁLISE CARTOGRÁFICA DAS ALTERAÇÕES DAS FEIÇÕES GEOMORFOLÓGICAS \\ DECORRENTES DA OCUPAÇÃO DA ILHA COMPRIDA/SP ENTRE 1962 E 2012}

Concomitantemente, cristas praiais se desenvolveram em paralelismo à linha de costa, até atingirem a região da atual área urbana de lguape.

- Seguiu-se novo período de transgressão marinha, há cerca de 3.500 anos A.P., no qual os cordões litorâneos foram parcialmente erodidos;

- Em seguida, uma segunda geração de cordões arenosos se formou a partir de novo abaixamento do nível do mar.

A Figura 2 mostra a sequência temporal da formação da Ilha Comprida, conforme Martin; Suguio (1978, p.912):

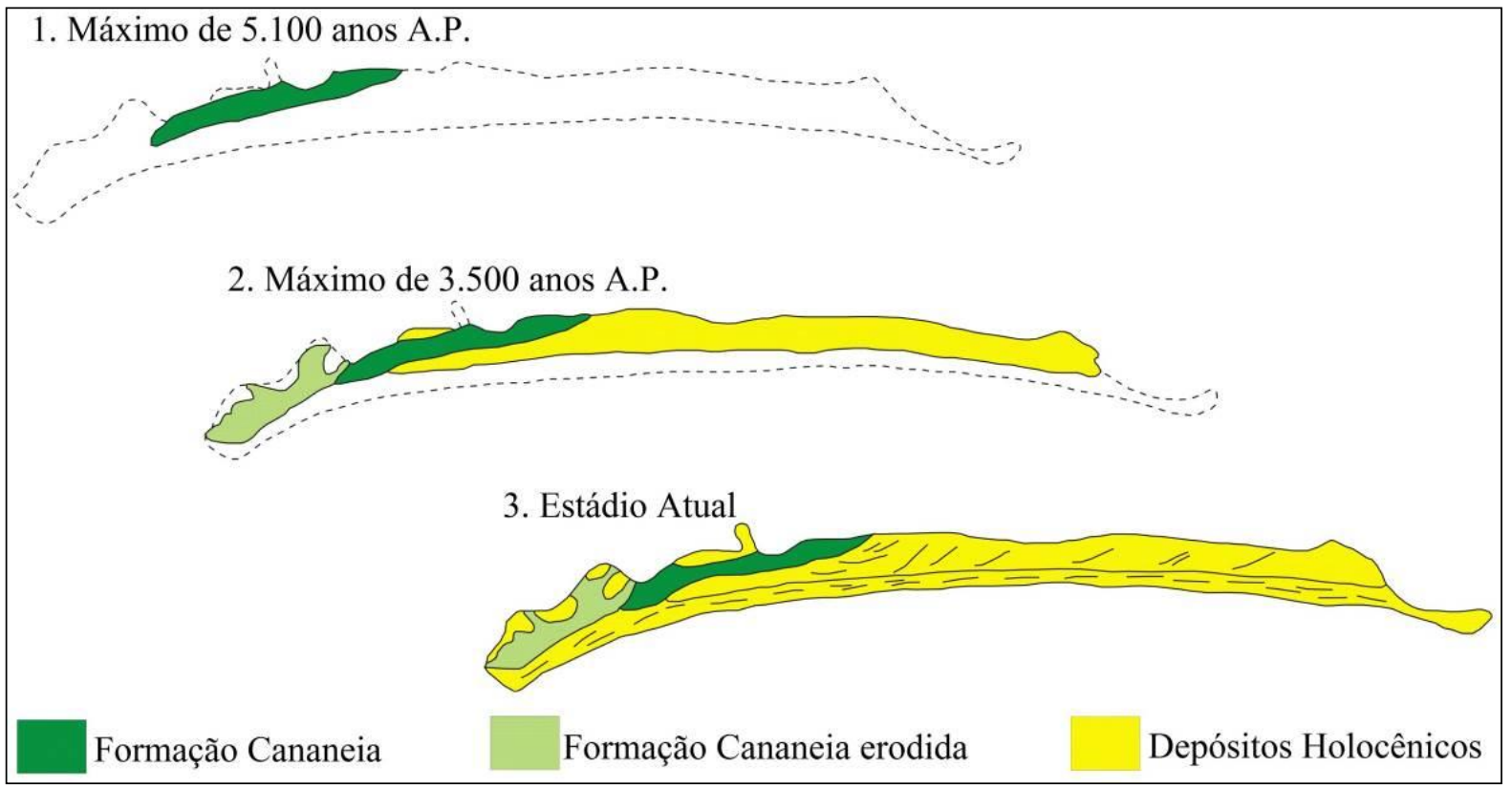

Figura 2: Estádios de evolução da llha Comprida.

Fonte: Adaptado de Martin; Suguio (1978, p.912).

De acordo com Almeida (1974, p.56), a área de estudo está localizada na chamada Província Costeira paulista, na subzona de Baixadas Litorâneas. Caracteriza-se pela presença de sedimentos arenosos essencialmente Quaternários (GIANNINI et al., 2009, p.177), com exceção ao Morrete, constituído por rochas que estão associadas ao Cretáceo Superior, com idade média de formação de 83,6 Milhões de anos (SPINELLI; GOMES, 2008, p.10).

As características geológicas influenciam nos tipos de solos ocorrentes na ilha, com destaque para os Espodossolos (COELHO et al. 2010, p.835) nos terraços marinhos, Neossolos Quartzarênicos (COELHO et al. 2010, p.843) nas dunas frontais, e Gleissolos Tiomórficos em planícies fluviomarinhas (OLIVEIRA; DIAS, 2012, p.136). 


\section{ANÁLISE CARTOGRÁFICA DAS ALTERAÇÕES DAS FEIÇÕES GEOMORFOLÓGICAS DECORRENTES DA OCUPAÇÃO DA ILHA COMPRIDA/SP ENTRE 1962 E 2012}

As propriedades pedológicas interferem no mosaico vegetacional existente na área de estudo. A mata de restinga ou "jundu" se estende pelos solos arenosos dos terraços marinhos; os mangues recobrem planícies fluviomarinhas banhadas pelos canais lagunares, drenagens de menor porte e ao longo dos rios Nóbrega e Boguaçu; herbáceas adaptadas a áreas constantemente alagadas demarcam as planícies fluviais do rio Candapuí e do córrego da Barra Nova; um fragmento de Mata Atlântica cobre o Morrete; e a vegetação fixadora de dunas se instala nas proximidades com as águas oceânicas.

\section{MATERIAIS E MÉTODOS}

A Cartografia Geomorfológica busca a espacialização dos fenômenos, de maneira que ao serem visualizadas as formas de relevo, representadas através de simbologias, seja possível compreender os processos responsáveis por suas gêneses. No entanto, destaca-se que não há uma padronização para as propostas de cartografia geomorfológica, visto que existe uma grande dificuldade em agrupar a diversidade de formas de relevo ocorrentes na superfície terrestre em uma única legenda. Neste sentido, diferentes propostas foram criadas para abarcarem as necessidades dos pesquisadores em distintas escalas de análise.

Ritchot (1970, p.369) propõe cartografia das feições do relevo em preto e branco, utilizando-se de exemplos na escala 1:25.000, com destaque para a morfografia, enquanto dados cronológicos estão indiretamente revelados pela disposição das formas. Verstappen; Van Zuidam (1975, p.15-16) propõem a cartografia geomorfológica a partir do uso de fotografias aéreas, afirmando que estes materiais apresentam, além da visualização das feições, a possibilidade de obtenção de dados morfométricos e litológicos com maior precisão, e salientam a possibilidade de aplicação em todas as escalas. IBGE (2009, p.18) apresenta os procedimentos de cartografia geomorfológica utilizados no Projeto RADAMBRASIL, em geral aplicados em estudos de escalas regionais.

A Cartografia Geomorfológica de Detalhe proposta por Jean Tricart (1965) busca a representação das feições do relevo com a maior proximidade possível da realidade geomorfológica da área de estudo. Neste sentido, Tricart (1965, p.187- 


\section{ANÁLISE CARTOGRÁFICA DAS ALTERAÇÕES DAS FEIÇÕES GEOMORFOLÓGICAS DECORRENTES DA OCUPAÇÃO DA ILHA COMPRIDA/SP ENTRE 1962 E 2012}

189) afirma que as cartas geomorfológicas devem conter a representação de quatro dados principais, a saber:

- Dados morfométricos: são dados essenciais que estão relacionados ao uso de cartas topográficas, como curvas de nível e drenagens;

- Dados morfográficos: refere-se à reprodução das formas do relevo através de simbologias apresentadas em uma legenda específica. O conjunto de simbologias deve representar as feições geomorfológicas, assim como seus aspectos morfogenéticos.

- Dados morfogenéticos: relativos à origem das formas do relevo. Análises laboratoriais e trabalhos de campo podem complementar ou confirmar a identificação da gênese das feições.

- Dados cronológicos: dizem respeito ao tempo necessário para a compreensão de como as formas do relevo se associaram, como ocorreram as oscilações climáticas, como foram geradas as formas sucessivas e quais as novas formas que estão se desenvolvendo.

As formas e os compartimentos de relevo presentes na llha Comprida foram identificados e cartografados com base na adaptação da legenda proposta pelo autor referido. Destaca-se que a legenda contempla com grande detalhamento o emprego de simbologias referentes a áreas litorâneas.

As Cartas Geomorfológicas dos cenários de 1962 e 1981 foram organizadas a partir de pares estereoscópicos de fotografias aéreas em formato digital, respectivamente nas escalas originais 1:25.000 e 1:35.000. Com a orientação dos procedimentos de Souza; Oliveira (2012b, p.1350-1353), foram elaboradas imagens tridimensionais através do uso do aplicativo computacional StereoPhoto Maker, para a visualização tridimensional do relevo com uso de óculos de 3D comum. As imagens em três dimensões foram georreferenciadas no ambiente digital do software ArcGIS $\AA$, com o auxílio da base cartográfica constituída por 25 folhas topográficas datadas de 1989 e adquiridas junto ao Instituto Geográfico e Cartográfico do estado de São Paulo, em escala 1:10.000.

Em seguida, shapefiles referentes à linha de costa, às ilhotas existentes nos canais lagunares, às drenagens perenes e temporárias e às lagoas perenes e 


\section{ANÁLISE CARTOGRÁFICA DAS ALTERAÇÕES DAS FEIÇÕES GEOMORFOLÓGICAS \\ DECORRENTES DA OCUPAÇÃO DA ILHA COMPRIDA/SP ENTRE 1962 E 2012}

temporárias foram criados para cada um dos cenários de análise, já que a llha Comprida apresenta grandes modificações destas variáveis.

A etapa seguinte constitui-se na elaboração das cartas geomorfológicas. Para 1962 e 1981, as feições do relevo foram identificadas diretamente sobre as imagens tridimensionais no ambiente do software ArcGIS®, com o uso dos óculos especiais.

Para o cenário de 2011-2012, foram utilizadas imagens orbitais do satélite Worldview-2 (Digital Globe), em escala 1:15.000 e composição colorida. As imagens, em formato digital, foram georreferenciadas com o uso da base cartográfica, e posteriormente ocorreu a interpretação visual das características geomorfológicas diretamente no ambiente do software ArcGIS®.

Considerando-se a proposta da Cartografia Geomorfológica de Detalhe de Tricart (1965), a legenda elaborada para as Cartas Geomorfológicas de 1962, 1981 e 2011-2012 foi organizada com a estrutura apresentada no Quadro 1.

\section{RESULTADOS E DISCUSSÃO}

O município de llha Comprida apresenta dois setores de características litológicas distintas: uma pequena porção constituída de rochas alcalinas sieníticas e uma grande área dominada por sedimentos arenosos Quaternários.

O setor de rochas alcalinas, conhecido como Morrete (Figura 3A), constitui-se como o ponto de litologia mais antiga da ilha e como único morro isolado da área de estudo, com altitude de $42 \mathrm{~m}$. Constitui-se de rochas resistentes aos processos erosivos em razão de sua constituição litológica, e seu maior desgaste é evitado por sua localização, possibilitando que não haja contato direto com o Mar de Cananeia e com o mar aberto, o que não permite o ataque direto de ondas e da elevação das marés.

Giannini et al. (2009, p.214) afirmam que o Morrete foi ponto de ancoragem dos depósitos sedimentares Quaternários que deram origem à ilha.

O topo do Morrete é caracterizado por formato convexo, arredondado e sem a presença de uma linha de cumeada bem definida. 


\section{ANÁLISE CARTOGRÁFICA DAS ALTERAÇÕES DAS FEIÇÕES GEOMORFOLÓGICAS DECORRENTES DA OCUPAÇÃO DA ILHA COMPRIDA/SP ENTRE 1962 E 2012}

\begin{tabular}{|c|c|c|c|c|c|}
\hline \multirow{2}{*}{$\begin{array}{l}\text { 1. Formas de } \\
\text { Vertentes e } \\
\text { Interflúvios }\end{array}$} & \multirow{2}{*}{$\begin{array}{l}\text { a. Precisões } \\
\text { Topográficas e } \\
\text { Morfométricas }\end{array}$} & \multicolumn{3}{|c|}{ Topo Arredondado } & \\
\hline & & \multicolumn{3}{|c|}{ Curvas de Nível } & - \\
\hline \multirow{7}{*}{$\begin{array}{l}\text { 2. Ação das } \\
\text { Águas } \\
\text { Correntes }\end{array}$} & \multirow{4}{*}{$\begin{array}{l}\text { b. Feições } \\
\text { Hidrográficas }\end{array}$} & \multicolumn{3}{|l|}{ Canal Perene } & \\
\hline & & \multicolumn{3}{|c|}{ Canal Temporário } & $\cdots$ \\
\hline & & \multicolumn{3}{|l|}{ Lagoa Perene } & \\
\hline & & \multicolumn{3}{|c|}{ Lagoa Temporária } & \\
\hline & \multirow{2}{*}{$\begin{array}{l}\text { c. Modelado de } \\
\text { Entalhe }\end{array}$} & \multicolumn{3}{|c|}{ Vale de Fundo Plano } & 1 \\
\hline & & \multicolumn{3}{|c|}{ Rebordo de Terraço Marinho } & \|\|\|\|\|\|$\|$ \\
\hline & $\begin{array}{l}\text { d. Formas de } \\
\text { Acumulação }\end{array}$ & \multicolumn{3}{|c|}{ Apf - Acumulação de Planície Fluvial } & \\
\hline \multirow{8}{*}{$\begin{array}{l}\text { 3. Ação } \\
\text { Marinha e } \\
\text { Litorânea }\end{array}$} & \multirow{8}{*}{$\begin{array}{l}\text { Formas de } \\
\text { Acumulação }\end{array}$} & \multirow{2}{*}{$\begin{array}{l}\text { Acumulação } \\
\text { Litorânea }\end{array}$} & \multirow{2}{*}{ Dunas } & Fixas & \\
\hline & & & & Desmanteladas & \\
\hline & & $\begin{array}{l}\text { Acumulação } \\
\text { Pré-Litorânea }\end{array}$ & \multicolumn{2}{|c|}{ Cordões Litorâneos } & \\
\hline & & \multicolumn{3}{|c|}{ Am - Acumulação Marinha Atual } & \\
\hline & & \multicolumn{3}{|c|}{$\begin{array}{l}\text { Atm I - Primeiro Nível de Acumulação de } \\
\text { Terraço Marinho }\end{array}$} & \\
\hline & & \multicolumn{3}{|c|}{$\begin{array}{l}\text { Atm II - Segundo nível de Acumulação de } \\
\text { Terraço Marinho }\end{array}$} & \\
\hline & & \multicolumn{3}{|c|}{$\begin{array}{l}\text { Atm III - Terceiro Nível de Acumulação de } \\
\text { Terraço Marinho }\end{array}$} & \\
\hline & & \multicolumn{3}{|c|}{$\begin{array}{l}\text { Apfm - Acumulação de Planície } \\
\text { Fluviomarinha }\end{array}$} & \\
\hline \multirow{2}{*}{$\begin{array}{l}\text { 4. Modelado } \\
\text { Antrópico }\end{array}$} & \multicolumn{4}{|c|}{ Superfície Construída } & \\
\hline & \multicolumn{4}{|l|}{ Ponte } & $\Longleftarrow$ \\
\hline \multirow{4}{*}{$\begin{array}{l}\text { 5. Litologia e } \\
\text { Cronologia }\end{array}$} & \multicolumn{4}{|l|}{ Rochas Alcalinas } & \\
\hline & \multicolumn{4}{|c|}{$\begin{array}{l}\text { Sedimentos de Mangue e de Pântano (Areias e Argilas) - } \\
\text { Holoceno Marinho e Lagunar }\end{array}$} & $\begin{array}{l}-\cdots-1 \\
\cdots-\cdots \\
\cdots-\cdots\end{array}$ \\
\hline & \multicolumn{4}{|c|}{$\begin{array}{l}\text { Areias Marinhas Litorâneas Trabalhadas em Superfície pelo } \\
\text { Vento }\end{array}$} & \\
\hline & \multicolumn{4}{|c|}{ Areias Marinhas Litorâneas } & \\
\hline & \multicolumn{4}{|c|}{ Estradas pavimentadas } & \\
\hline 6. Convencões & Estradas não-pa & nentadas & & & (n.................... \\
\hline Cartográficas & Caminhos e trilh & & & & (..................... \\
\hline & Linhas de costa & & & & - \\
\hline
\end{tabular}

Quadro 1 - Legenda das cartas geomorfológicas de 1962, 1981 e 2011-2012

Fonte: organizada com base na proposta de Tricart (1965).

Organização das autoras (2014). 


\section{ANÁLISE CARTOGRÁFICA DAS ALTERACÕES DAS FEICÕES GEOMORFOLÓGICAS DECORRENTES DA OCUPAÇÃO DA ILHA COMPRIDA/SP ENTRE 1962 E 2012}

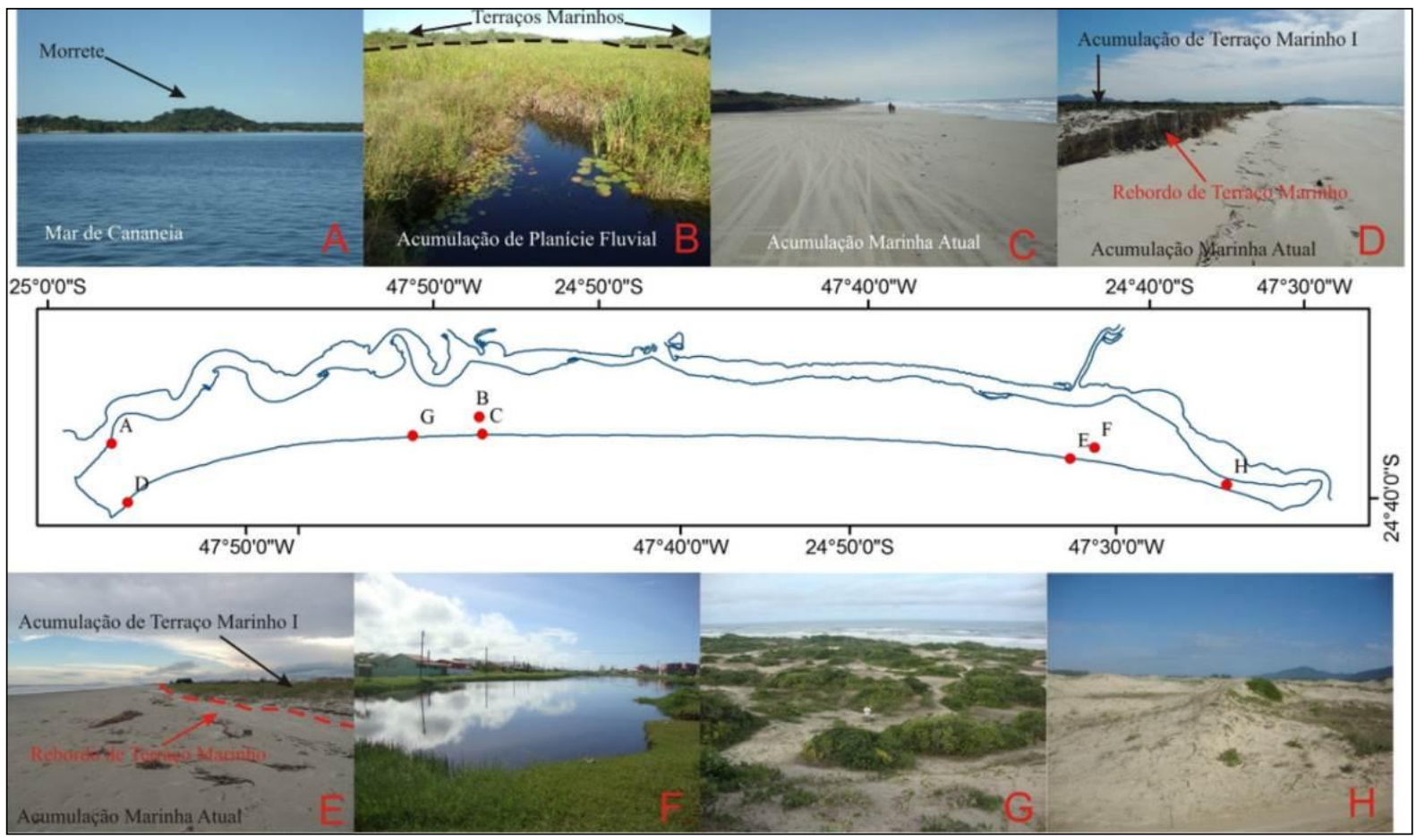

Figura 3- Compartimentos e formas de relevo da llha Comprida.

Fonte: Acervo das autoras (2011-2014). Fotos obtidas durante trabalhos de campo.

O setor sedimentar, por sua vez, foi compartimentado a partir de pesquisas bibliográficas sobre a área de estudo, da consulta de cartas geológicas e da interpretação de fotografias aéreas e de imagens de alta resolução. Optou-se pela inserção de letras-símbolos presentes na proposta de IBGE (2009), que objetivam a diferenciação dos compartimentos geomorfológicos sedimentares conforme a origem e os processos que atuam em sua formação. Desta maneira, foram definidos para a Ilha Comprida: um nível de Acumulação de planície fluvial (Apf), um nível de Acumulação Marinha Atual (Am), um nível de Acumulação de planície fluviomarinha (Apfm), e três níveis de Acumulação de terraços marinhos (Atm I, Atm II, Atm III) (Figura 4).

Estes compartimentos não são estáticos, e apresentam variações em área ao longo dos cenários, como é possível observar na Tabela 1.

Os compartimentos apresentados na Tabela 1 e na Figura 4 estão descritos a seguir:

- Acumulação de planície fluvial (Apf): caracteriza-se como uma zona pantanosa ao longo do rio Candapuí (Figura 3B) e do córrego da Barra Nova, com cerca de $2 \mathrm{~m}$ de altitude, que se encontra embutida nos terraços marinhos de nível II ou entre a 


\section{ANÁLISE CARTOGRÁFICA DAS ALTERAÇÕES DAS FEICCÕES GEOMORFOLÓGICAS DECORRENTES DA OCUPAÇÃO DA ILHA COMPRIDA/SP ENTRE 1962 E 2012}

Atm III e a Atm II. A Apf apresenta pequena alteração em área ocupada, de acordo com a Tabela 1.

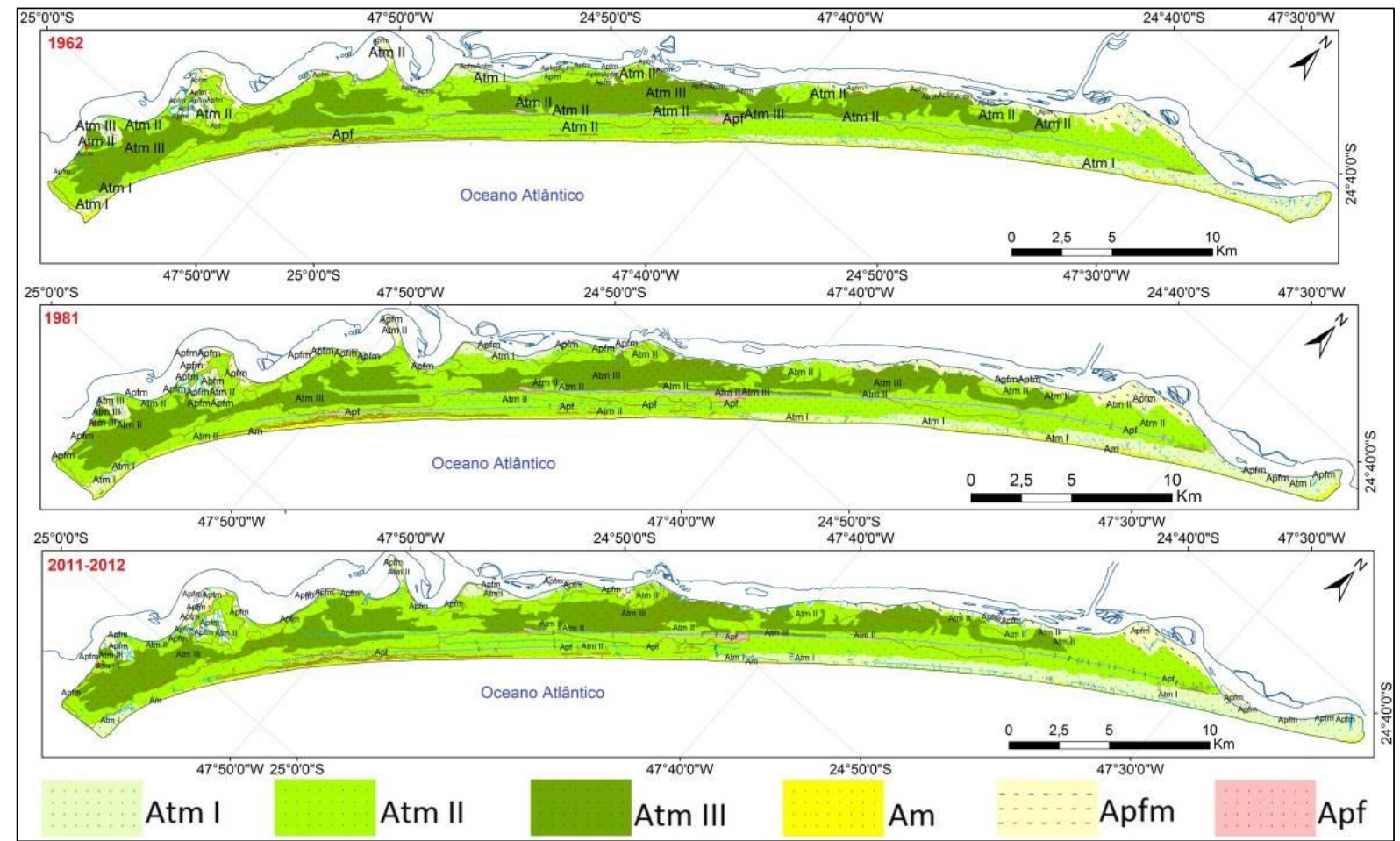

Figura 4 - Compartimentação geomorfológica da área de estudo para os cenários de 1962, 1981 e 2011-2012.

Fonte: Organização das Autoras (2014).

Tabela 1 - Área ocupada $\left(\mathrm{em} \mathrm{km}^{2}\right)$ pelos compartimentos do relevo do setor sedimentar da llha Comprida para os cenários de 1962, 1981 e 2011-2012.

\begin{tabular}{c|c|c|c}
\hline \multirow{2}{*}{ Compartimentos } & \multicolumn{3}{|c}{ Área em $\mathrm{Km}^{2}$} \\
\cline { 2 - 4 } & 1962 & 1981 & $2011-2012$ \\
\hline Apf & 4,90 & 5,19 & 4,66 \\
Am & 7,70 & 8,64 & 6,04 \\
Apfm & 17,92 & 16,52 & 16,61 \\
Atm I & 15,62 & 17,30 & 21,00 \\
Atm II & 86,23 & 89,84 & 92,87 \\
Atm III & 55,66 & 52,91 & 48,84 \\
\hline
\end{tabular}

Fonte: Organização das autoras (2014).

- Acumulação marinha atual (Am) (Figura 3C): a Am exibe expressiva variação em área (Tabela 1), o que indica dinâmica heterogênea que se associa a variações das marés em diferentes épocas do ano, ventos, ocorrência de tempestades, ação das ondas, e atuação das drenagens que deságuam no mar aberto. Área de interesse turístico pois comporta as praias arenosas, e pressão antrópica constante pela utilização de automóveis. 


\section{ANÁLISE CARTOGRÁFICA DAS ALTERAÇÕES DAS FEIÇÕES GEOMORFOLÓGICAS DECORRENTES DA OCUPAÇÃO DA ILHA COMPRIDA/SP ENTRE 1962 E 2012}

- Acumulação de planície fluviomarinha (Apfm): compartimento localizado na margem lagunar da ilha e no entorno dos rios Nóbrega e Boguaçu. A evolução da Apfm está associada a barras arenosas emersas e submersas que são fixadas por vegetação de mangue, podendo formar ilhotas, que em alguns pontos estão em processo de acoplamento com a llha Comprida.

- Acumulação de terraço marinho I (Atm I): nível mais baixo que apresenta tendência de acréscimo em área entre 1962 e 2011-2012 (Tabela 1), relacionada com a exposição deste compartimento por erosão de níveis superiores e por evolução do setor Nordeste da Ilha Comprida. As altitudes variam entre 1 e $3 \mathrm{~m}$, no entanto, no Campo de Dunas do Araçá podem alcançar até $14 \mathrm{~m}$.

- Acumulação de terraço marinho II (Atm II): nível intermediário com aumento de área ocupada entre os cenários analisados (Tabela 1). Nível de terraço mais suscetível à ação dos canais de drenagem, sendo que em períodos de inundação a água atinge o rebordo dos terraços marinhos no entorno do rio Candapuí e do córrego da Barra Nova. Henrique e Mendes (1999, p.86) destacam que durante a elevação das marés, as águas marinhas invadem as drenagens e penetram nos terraços marinhos, provocando a erosão das margens dos canais por desbarrancamento. Isto também pode ser aplicado à Atm I e à Am, que também apresentam drenagens que deságuam no mar aberto. As altitudes na Atm II podem variar entre 2 e $8 \mathrm{~m}$, atingindo até $14 \mathrm{~m}$ no Campo de Dunas de Juruvaúva.

- Acumulação de terraço marinho III (Atm III): compartimento com altitudes entre 6 e 11 m, que apresenta redução de área entre 1962 e 2011-2012 (Tabela 1), que pode estar associada a processos erosivos desencadeados pelo desnível altimétrico, relacionado com suas características litológicas.

As formas de relevo representadas nas cartas geomorfológicas por simbologias pontuais e lineares são os rebordos de terraços marinhos, cordões litorâneos, dunas fixas, dunas desmanteladas e vales de fundo plano. Além disto, a área se caracteriza pela presença de drenagens perenes e temporárias, e lagoas perenes e temporárias.

- Rebordo de terraços marinhos: delimitam os diferentes níveis de Atm e demarcam a ruptura topográfica entre os terraços marinhos e a Am, e entre os terraços 


\section{ANÁLISE CARTOGRÁFICA DAS ALTERAÇÕES DAS FEIÇÕES GEOMORFOLÓGICAS DECORRENTES DA OCUPAÇÃO DA ILHA COMPRIDA/SP ENTRE 1962 E 2012}

marinhos e as planícies fluviomarinhas. Em segmentos da llha Comprida caracterizados por processos erosivos, como é o caso do Pontal da Trincheira (SADOWSKY, 1952, p.202) e da Ponta da Praia, os rebordos de terraços marinhos são bem definidos, formando degraus topográficos que mostram transição abrupta entre os compartimentos do relevo (Figura 3D). Constatam-se também rebordos de terraços marinhos com transições suaves, como foi observado no Boqueirão Norte (setor NE da llha Comprida) (Figura 3E), durante trabalho de campo.

- Vales de fundo plano: ocorrem em todos os compartimentos sedimentares. Formas associadas com as baixas declividades da ilha, que predominam entre 0 e 2o (LIMA, 2011, p.90-91).

- Cordões litorâneos: formas cartografadas em todos os níveis de terraços marinhos, desde as proximidades com a linha de costa até as áreas interiores adjacentes aos canais lagunares. $O$ paralelismo existente indica o processo de "engorda" da ilha, que se associa à regressão do nível marinho até seu estádio atual (HENRIQUE; MENDES, 1999, p.78). As curvaturas indicam o crescimento longitudinal da ilha em sentido Nordeste, em concordância com o atual rumo de transporte sedimentar predominante no litoral Sul do estado de São Paulo (TESSLER, 1988, citado por GUEDES, 2009, p.14).

As extremidades da ilha são caracterizadas pelo truncamento e subparalelismo de cordões litorâneos com a linha de costa, devido à atuação de antigos fluxos de correntes responsáveis pela direção da deposição de material sedimentar. No Pontal da Trincheira, Guedes (2009, p.53) afirma que podem ser diferenciadas até cinco áreas distintas com base na orientação dos cordões, que são visualizadas na forma triangular, com leve inclinação em sentido W. Na Ponta da Praia, os feixes de cordões litorâneos indicam o atual predomínio do crescimento longitudinal da ilha em direção ao Nordeste. Observam-se cordões litorâneos perpendiculares à Praia da Ilha Comprida, porém estes mesmos feixes são paralelos à linha de costa banhada pela Barra de Icapara.

- Lagoas perenes/Lagoas temporárias: estão associadas ao lençol freático raso e à proximidade com o nível de base (Oceano Atlântico). A Figura 3F mostra uma lagoa perene localizada em meio à área urbana, no setor Nordeste da ilha. 


\section{ANÁLISE CARTOGRÁFICA DAS ALTERAÇÕES DAS FEIÇÕES GEOMORFOLÓGICAS DECORRENTES DA OCUPAÇÃO DA IĽHA COMPRIDẢ/SP ENTRE 1962 E 2012}

- Dunas fixas: feições cobertas por vegetação, mapeadas para toda a margem oceânica da llha Comprida nos níveis de terraços marinhos I e II. Tem-se destaque o Campo de Dunas de Juruvaúva (Figura 3G), por apresentar dunas bem desenvolvidas fixadas por vegetação.

- Dunas desmanteladas: refere-se ao Campo de Dunas do Araçá (Figura 3H) estabelecido sobre Atm I. É um campo de dunas ativo, no qual é possível observar o deslocamento de sedimentos pela ação eólica e cobertura vegetal incipiente. Nascimento Junior et al. (2008, p.35) apontam duas hipóteses para o surgimento deste campo de dunas: a primeira, que sua origem pode estar ligada à ampliação do canal do Valo Grande (município de Iguape) pela erosão, entre os anos de 1870 e 1910, o que proporcionaria excesso de sedimentos disponíveis na região da desembocadura lagunar de Icapara. A segunda proposição, conforme os autores, é o estreitamento da extremidade Nordeste da Ilha Comprida, de maneira que "[...] uma redução no espaço de acumulação poderia "saturar" areia em trecho reduzido, culminando no crescimento de um campo de dunas".

Elencados os compartimentos e as formas de relevo, mapeados para a área de estudo, é possível a realização de uma análise sobre as alterações geomorfológicas ocorridas entre os cenários de 1962, 1981 e 2011-2012. Para a análise temporal do relevo da área, foram selecionados pontos de amostragem nos quais ocorreram as maiores modificações para os cenários analisados.

O cenário mais antigo é caracterizado por feições geomorfológicas bem preservadas. Os diferentes níveis de terraços marinhos são marcados por transições bem definidas e a conservação da vegetação original de restinga auxilia na demarcação destes diferentes níveis. As transições entre terraços marinhos e planícies fluviomarinhas também são cartografadas com precisão. As áreas de dunas não apresentam intervenções que possibilitem apontar degradação ou reativação.

Apesar do predomínio de atributos naturais, observam-se as primeiras intervenções humanas sobre o relevo no setor SW da ilha. A implantação do Balneário Vila Rica promoveu a interrupção (ou "quebra") de cordões litorâneos, como indicado na Figura 5 pelos retângulos na cor magenta: 


\section{ANÁLISE CARTOGRÁFICA DAS ALTERAÇÕES DAS FEIÇÕES GEOMORFOLÓGICAS DECORRENTES DA OCUPAÇÃO DA ILHA COMPRIDA/SP ENTRE 1962 E 2012}

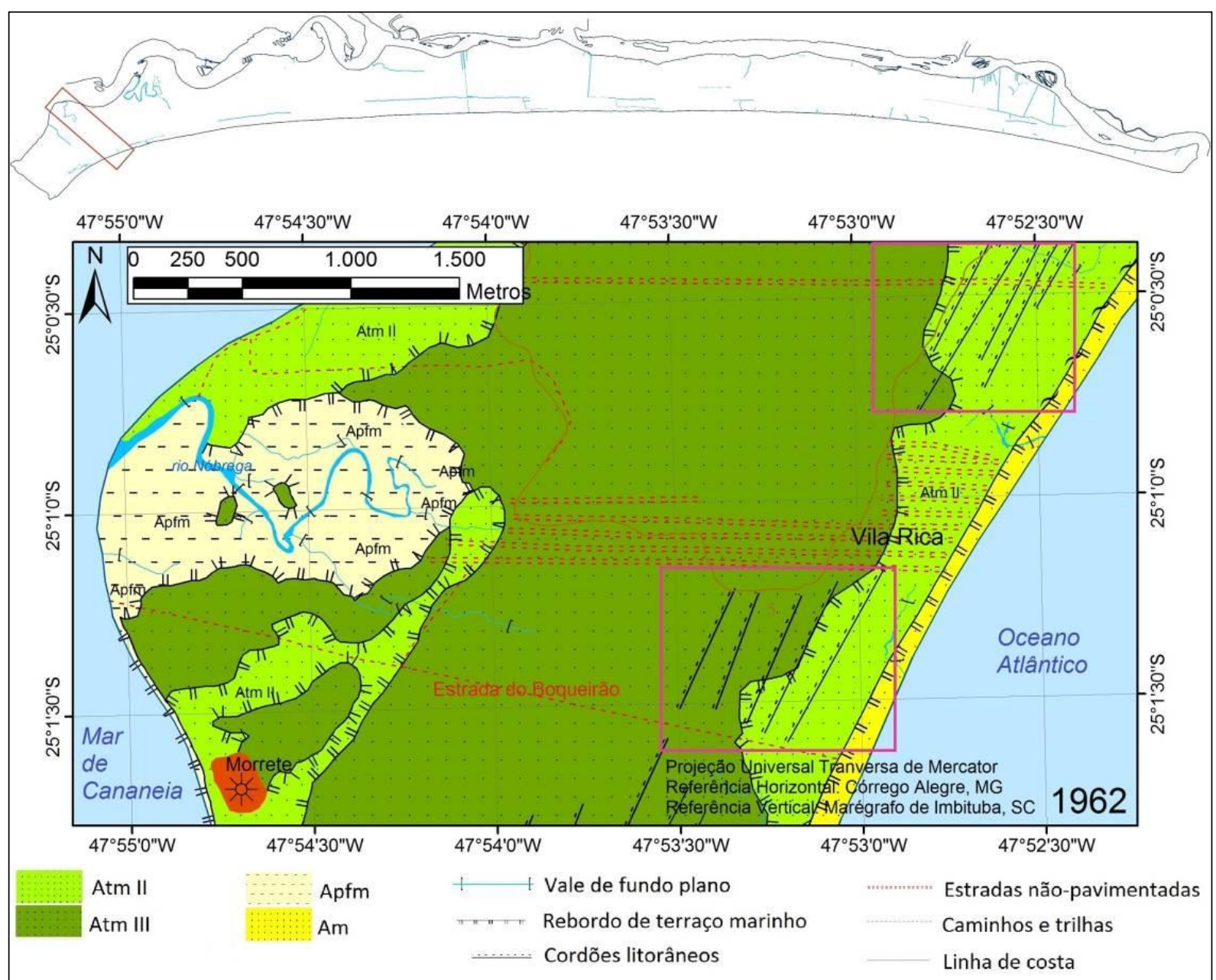

Figura 5 - Descontinuidades de cordões litorâneos no setor Sudoeste da llha Comprida, cenário de 1962.

Fonte: Organização das autoras (2014).

Os primeiros loteamentos abertos na llha Comprida estavam localizados nas proximidades das estradas de acesso às balsas de interligação com os núcleos urbanos de Iguape e Cananeia. No setor SW, a ligação para a balsa e a cidade de Cananeia é feita até os dias atuais pela Estrada do Boqueirão. No trecho NE, a ligação entre os loteamentos da llha Comprida e a balsa para o núcleo urbano de Iguape se fazia pela atual Rua Franca. A partir do ano de 2000, Iguape e Ilha Comprida passaram a estar conectadas pela Ponte Prefeito Laércio Ribeiro, com consequente desativação da balsa.

Para o cenário de 1962, observa-se que os arruamentos apresentam padrão de organização perpendicular à linha de costa, com início na orla litorânea e estendendo-se em direção ao interior da Ilha Comprida. 


\section{ANÁLISE CARTOGRÁFICA DAS ALTERACÕES DAS FEIC̄õES GEOMORFOLÓGICAS DECORRENTES DA OCUPAÇÃO DA ILHA COMPRIDA/SP ENTRE 1962 E 2012}

No setor NE, chamado popularmente de "Boqueirão Norte", os primeiros loteamentos - Britânia, Sete de Setembro e Vila Real - se estendem sobre áreas de dunas, de terraços marinhos de nível I, II e III, da planície fluvial do rio Candapuí, e em alguns trechos até a planície fluviomarinha. Cordões litorâneos segmentados são observados, porém tais descontinuidades estão associadas à ocorrência de canais de drenagem que deságuam no Oceano Atlântico (Figura 6-1962). Constatam-se curvaturas nos cordões litorâneos internos, que indicam o sentido Nordeste de crescimento longitudinal da ilha.

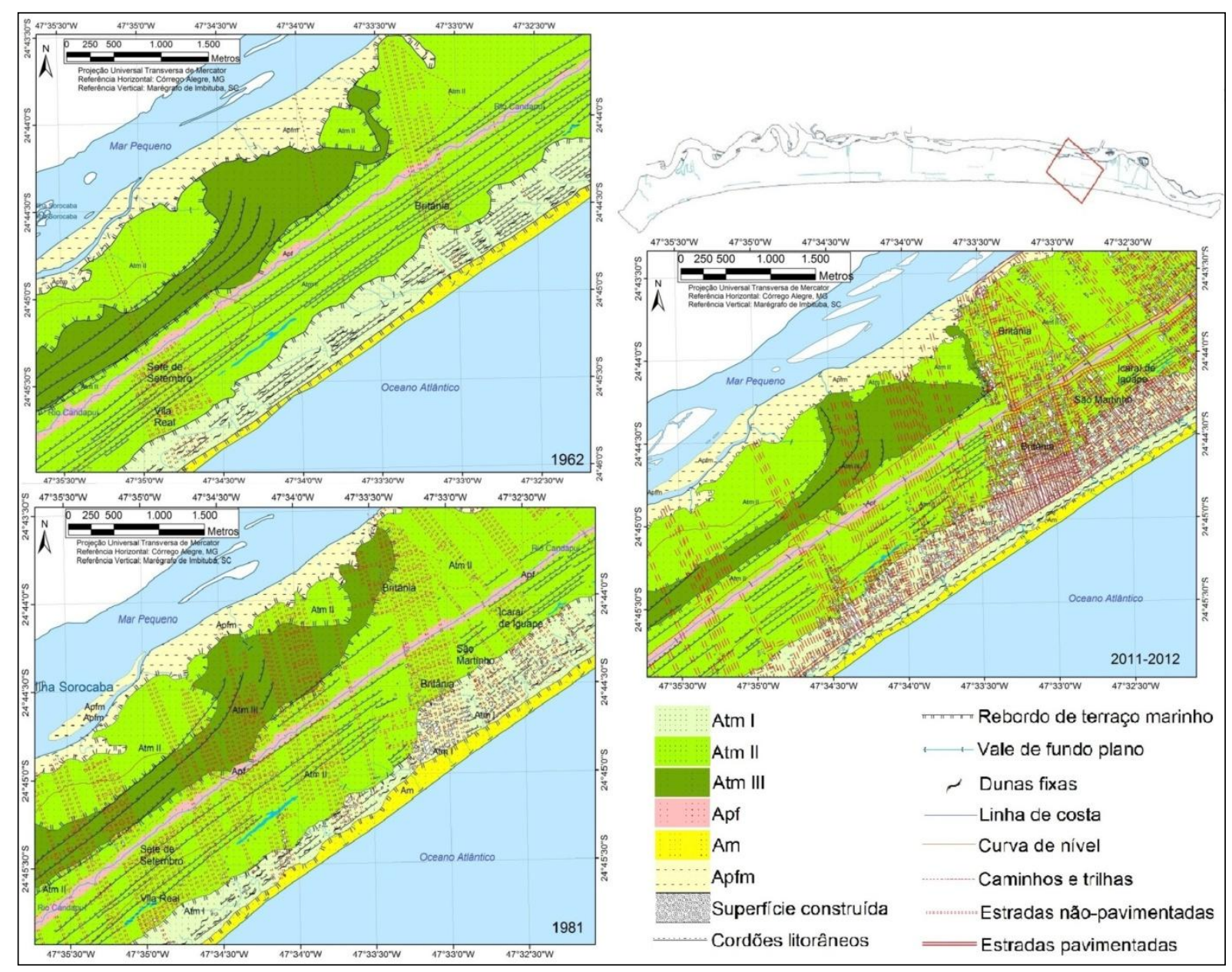

Figura 6 - Modificações temporais do relevo na porção Nordeste da llha Comprida.

Fonte: Organização das autoras (2014).

Entre os cenários de 1962 e 1981, são verificadas grandes alterações nas características do relevo da Ilha Comprida, associadas sobretudo à especulação imobiliária. Durante a elaboração da Carta Geomorfológica para o cenário de 1981, observou-se que a realização de obras de terraplanagem provocaram modificações nos limites dos terraços marinhos, o que dificultou o mapeamento das transições. 


\section{ANÁLISE CARTOGRÁFICA DAS ALTERAÇÕES DAS FEIÇÕES GEOMORFOLÓGICAS \\ DECORRENTES DA OCUPAÇÃO DA ILHA COMPRIDA/SP ENTRE 1962 E 2012}

Áreas de dunas foram alteradas para a instalação de loteamentos e obras de aterramento ocorreram nas planícies fluviomarinhas, o que também modificou a visualização dos limites entre estes compartimentos e os terraços marinhos.

Na Figura 6, para o cenário de 1981, observa-se que os cordões litorâneos tornaram-se descontínuos em locais de abertura de arruamentos, e até mesmo não puderam ser cartografados vestígios de suas disposições originais, como por exemplo, no Balneário Britânia, onde também se averígua o início da formação da área urbana.

As edificações foram implantadas em áreas onde originalmente se localizavam dunas fixadas por vegetação e cordões litorâneos. Já os aspectos dos arruamentos seguem os padrões observados em 1962, ocorrendo também vias paralelas à linha de costa.

Maretti; Filet (1988, p.71) destacam que diversas ruas foram construídas sobre aterros que cortavam cursos d'água. Este procedimento resultou no alagamento de vias, transformando-as em locais de escoamento de drenagem.

Entre 1981 e 2011-2012, constata-se que as mudanças do relevo continuam a estar associadas ao crescimento urbano e ao número de arruamentos.

A partir da observação da Figura 6, para o cenário de 2011-2012, averígua-se que as principais alterações do relevo estão situadas entre a orla litorânea e a planície fluvial do rio Candapuí. As modificações do relevo constatadas em 1981 tornam-se mais evidentes no cenário de 2011-2012, como a "quebra" e desaparecimento de cordões litorâneos. Quando segmentadas, estas formas de relevo se tornam mais expostas à ação dos ventos, das águas e das atividades antrópicas, como a extração de areia para uso na construção civil. Ocorre também a modificação do sistema interno de drenagem da ilha, visto que cursos d'água, principalmente aqueles localizados na face oceânica, seguem a direção dos alinhamentos dos cordões.

Com a especulação imobiliária na llha Comprida, trechos anteriormente ocupados por feições dunares foram cobertos pela área urbana. Na Figura 6, ressalta-se que o crescimento de superfícies construídas formou uma mancha contínua, aliada com a presença de ruas e de avenidas asfaltadas. 


\section{ANÁLISE CARTOGRÁFICA DAS ALTERAÇÕES DAS FEIÇÕES GEOMORFOLÓGICAS \\ DECORRENTES DA OCUPAÇÃO DA ILHA COMPRIDA/SP ENTRE 1962 E 2012}

O asfaltamento promove a impermeabilização do solo e a aceleração do escoamento superficial, o que pode dinamizar a ocorrência de inundações frequentes em períodos chuvosos.

Maretti; Filet (1988, p.71) apontam na década de 1980 a ocorrência de "corte" nas dunas para que os veículos possam ter acesso à praia, situação verificada nos dias atuais através de trabalhos de campo. A retirada de vegetação das dunas, que são responsáveis pela fixação dos sedimentos, expõe a forma de relevo à ação direta dos ventos, desencadeando processos de reativação e promovendo um novo deslocamento dos depósitos arenosos, que podem passar a se depositar em áreas construídas.

Maretti; Filet (1988, p.71) destacam também a retirada de sedimentos das áreas dunares para a construção da Avenida Beira-Mar e para preenchimento de terrenos alagadiços. A Avenida Beira-Mar, que se estende do Campo de Dunas do Araçá até o córrego da Barra Velha delimitou a área de ocorrência das feições dunares, o que pode ser verificado na Figura 6, no cenário mais recente de análise.

Trechos de dunas aplainados para a inserção de atividades recreativas foram averiguados em trabalho de campo, com a presença de quadras para práticas de esportes, campos de futebol e instalação temporária de parques de diversão. No Boqueirão Norte há uma pista para a prática de corridas automobilísticas.

Sobre as feições dunares, como destaca notícia na página virtual da Prefeitura Municipal, no dia 08/05/2015, foram iniciadas as obras referentes ao projeto de Requalificação Ambiental da orla da ilha no Boqueirão Norte, visando a construção de novas estruturas, com calçadas, ciclovias, e passarelas suspensas sobre as dunas, visando a proteção do sistema que ainda resta, e não será permitida a entrada de veículos automotivos na praia.

Enfatiza-se a existência de canais de drenagem artificiais localizados nas dunas frontais e que deságuam diretamente em mar aberto. Estes canais podem desencadear processos erosivos na Acumulação marinha atual e nas áreas dunares, pois se tornam local de entrada das águas durante as marés altas e durante eventos de tempestades. 


\section{ANÁLISE CARTOGRÁFICA DAS ALTERAÇÕES DAS FEIÇÕES GEOMORFOLÓGICAS \\ DECORRENTES DA OCUPAÇÃO DA ILHA COMPRIDẢSP ENTRE 1962 E 2012}

No trecho central da Ilha Comprida, observam-se os mesmos padrões de modificação do relevo constatados para o trecho Nordeste, como pode ser constatado na sequência temporal da Figura 7.

Para o cenário de 1962, o setor central da ilha não apresenta grandes interferências antrópicas, com exceção a caminhos e trilhas abertos para o deslocamento interno na ilha.

Para o cenário de 1981, verificam-se arruamentos e a implantação das primeiras edificações no Balneário Diamante. Os arruamentos se estendem até a planície fluviomarinha, passando também por áreas de planície fluvial. Estes dois compartimentos caracterizam-se como áreas inundáveis, pouco propícias à instalação de construções. Constatam-se segmentações nos cordões litorâneos, que ocorrem tanto no trecho entre a orla e o rio Candapuí, como entre o rio Candapuí e a margem lagunar.

Para 2011-2012, observa-se no Balneário Diamante e no entorno do córrego da Barra Velha o desaparecimento de cordões litorâneos e a alteração de áreas dunares pelo aumento do número de edificações.

A extremidade Nordeste da Ilha Comprida também foi afetada pela especulação imobiliária, como é possível constatar na sequência temporal da Figura 8.

Para o cenário de 1962, nota-se a não intervenção humana, enquanto para 1981, averígua-se que a especulação imobiliária alcançou este setor da ilha. O Balneário Praia do Araçá localiza-se sobre nível de terraço marinho I e na transição para a Atm II, com presença de cordões litorâneos internos e cordões litorâneos trabalhados em superfície pelo vento nas proximidades com a Praia da llha Comprida. O Balneário foi instalado em uma área de transição entre dunas estabilizadas por vegetação típica e dunas móveis. Portanto, esta área é bastante suscetível à reativação de dunas estabilizadas e ao deslocamento e acúmulo de sedimentos das feições dunares ainda instáveis. 


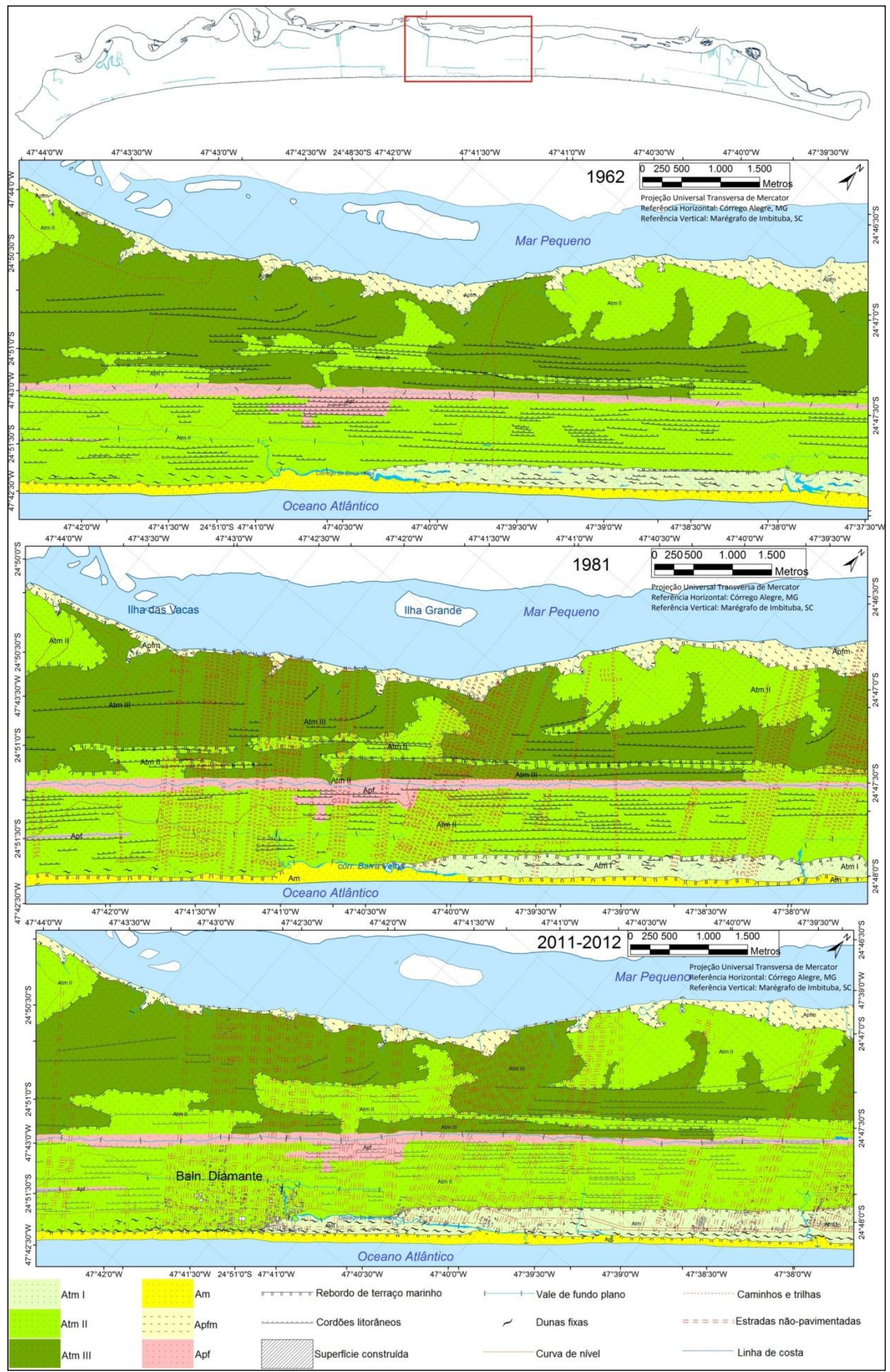

Figura 7 - Alterações temporais do relevo no trecho central da llha Comprida. Fonte: Organização das autoras (2014). 


\section{ANÁLISE CARTOGRÁFICA DAS ALTERACÕES DAS FEICÕES GEOMORFOLÓGICAS DECORRENTES DA OCUPAÇÃO DA ILHA COMPRIDA/SP ENTRE 1962 E 2012}

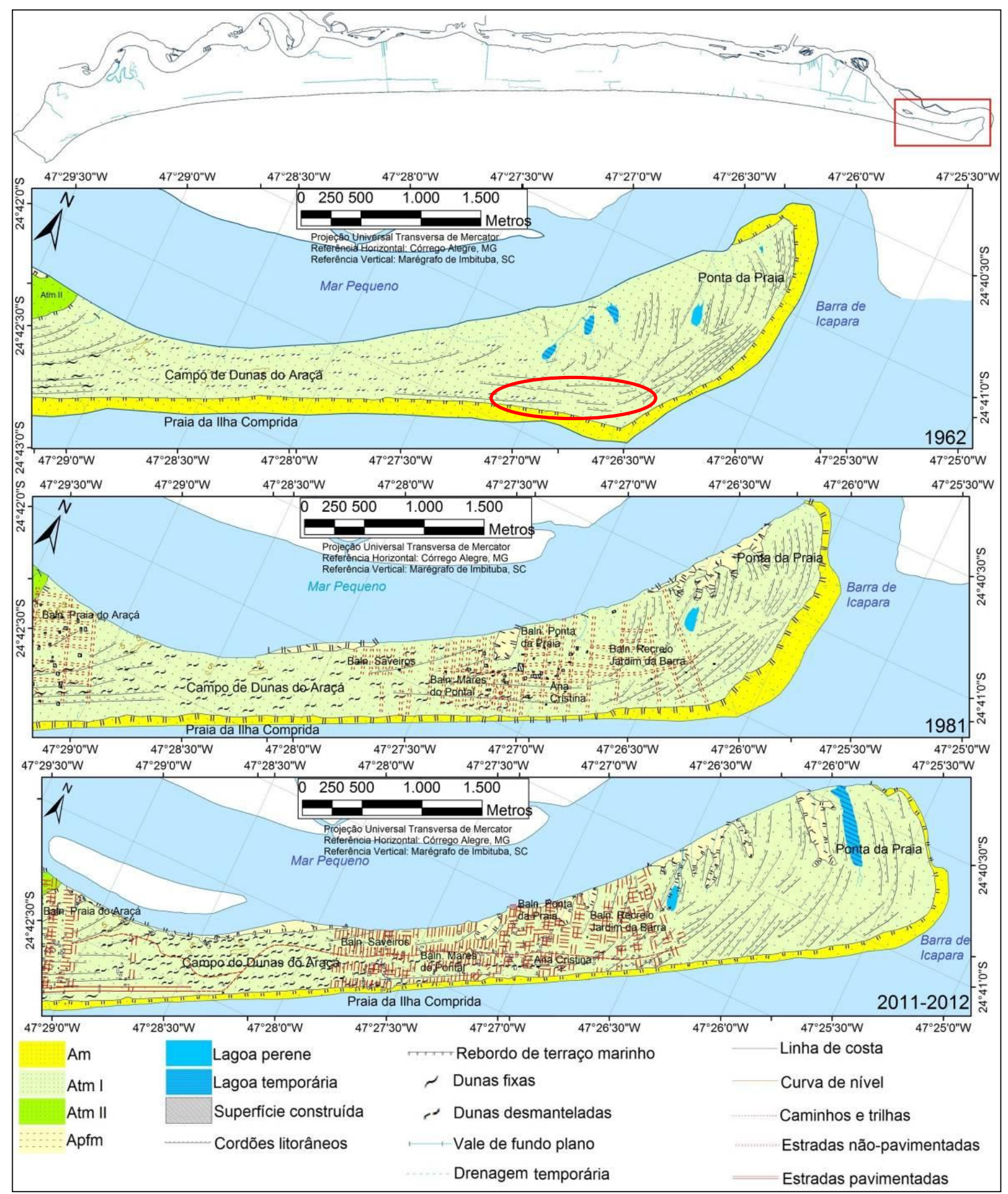

Figura 8 - Alterações geomorfológicas na extremidade Nordeste e disposição dos loteamentos e da área urbana sobre as formas de relevo.

Fonte: Organização das autoras (2014).

Os balneários denominados Saveiros, Mares do Pontal, Ponta da Praia, Ana Cristina e Recreio Jardim da Barra estão localizados em área sujeita aos processos erosivos eólicos, em razão da presença do Campo de Dunas do Araçá. Em trabalho de campo, foi possível observar que edificações foram construídas em meio às 


\section{ANÁLISE CARTOGRÁFICA DAS ALTERAÇÕES DAS FEIÇÕES GEOMORFOLÓGICAS DECORRENTES DA OCUPAÇÃO DA ILHA COMPRIDA/SP ENTRE 1962 E 2012}

áreas dunares, estando sujeitas a se tornarem pontos de deposição de sedimentos arenosos por ação eólica.

A face oceânica da extremidade NE da ilha é caracterizada pela ação da erosão marinha. Para o ano de 1962 nota-se a presença de um esporão arenoso, em destaque pelo círculo vermelho na Figura 8. Conforme Nascimento Junior et al. (2008, p.35), o predominante crescimento longitudinal da Ilha Comprida para rumo Nordeste levou o esporão a ser erodido pela dinâmica marinha, tendo como consequência a modificação da linha de costa através de processo erosivo atuante até os dias atuais. Nos cenários de 1981 e 2011-2012, constata-se a tendência de retilinização da linha de costa, estreitamento da Am e convexização da Ponta da Praia. A erosão marinha, que foi observada durante trabalhos de campo relativos a esta pesquisa, avança sobre a Am e sobre a Atm I atingindo edificações que em períodos anteriores se situavam próximas à praia. A transição entre o terraço marinho e a Am é marcada por um degrau topográfico evidente, consequente da atuação da dinâmica marinha na área.

Por último, destaca-se que o Pontal da Trincheira (extremidade SW da ilha) é marcado pela ação natural na dinâmica do relevo, já que esta área apresenta uma baixa ocupação humana. As feições geomorfológicas encontram-se bem preservadas, com sua evolução associada à escavação das drenagens promovendo a alteração do rebordo do terraço marinho entre Atm I e Atm II e ações de correntes de maré, ondas e correntes de deriva litorânea (TESSLER et al., 1990, p.26), promovendo a modificação da Am e da Atm II.

\section{CONSIDERAÇÕES FINAIS}

A Ilha Comprida é um ambiente de grandes alterações naturais da paisagem devido à sua localização geográfica na interface entre oceano e continente, aliada à sua constituição litológica por sedimentos arenosos recentes. O único ponto da ilha no qual ocorrem rochas mais resistentes à ação do intemperismo é o Morrete. Apesar da intensa especulação imobiliária, a ilha caracteriza-se pela presença de formas do relevo bem preservadas, como Campos de Dunas e cordões litorâneos que assinalam antigas posições de linha de costa. 


\section{ANÁLISE CARTOGRÁFICA DAS ALTERAÇÕES DAS FEIÇÕES GEOMORFOLÓGICAS DECORRENTES DA OCUPAÇÃO DA ILHA COMPRIDA/SP ENTRE 1962 E 2012}

No cenário de 1962, devido à preservação das características naturais, é possível associar as formas de relevo aos seus processos naturais geradores, de maneira que sua análise possa se basear em sistemas de processos-respostas, apesar de ocorrerem as primeiras intervenções antrópicas através da abertura de loteamentos e de caminhos e trilhas.

Para os cenários de 1981 e 2011-2012, foram observadas grandes modificações das características geomorfológicas, ligadas, sobretudo, à especulação imobiliária e ao crescimento urbano. A análise das alterações do relevo pode se pautar nos sistemas controlados, já que as atividades humanas passam a exercer interferência na dinâmica do relevo.

Uma das principais mudanças observadas na área foi o fracionamento de cordões litorâneos, que pode desencadear erosão por ação da água, do vento e por ações antrópicas. Verificou-se principalmente nos trechos central e Nordeste da ilha o desaparecimento destas formas do relevo, pela ocorrência de terraplanagem e desenvolvimento da mancha urbana.

Sobre as áreas de dunas, pode-se afirmar que a retirada de sedimentos pode gerar déficit de depósitos disponíveis para a manutenção do equilíbrio praial, o que pode desencadear ação da erosão marinha com consequente retrogradação da linha de costa. Medidas como o projeto de Requalificação Ambiental da orla do Boqueirão Norte poderiam ser estendidas a outras áreas de concentração de população na orla da ilha, assim como ao Campo de Dunas de Juruvaúva, no qual acontecem trilhas de turismo, evitando a degradação das feições e da cobertura vegetal, e ao Campo de Dunas do Araçá, que é trecho de fácil acesso à população, onde ocorre pisoteio das feições e prática de esportes radicais com uso de motocicletas.

Com relação às planícies fluviomarinhas, nas quais em diversos pontos ao longo da margem lagunar apresentam arruamentos, deve-se ressaltar que seus terrenos alagadiços são áreas propícias somente para a manutenção da biodiversidade.

Pode-se afirmar que a utilização da Cartografia Geomorfológica possibilita a espacialização precisa das formas de relevo, assim como permite analisar quais os fatores responsáveis pelas transformações temporais das características 
geomorfológicas. O emprego deste documento cartográfico possibilita planejar e direcionar a instalação humana, evitando que setores mais suscetíveis como planícies fluviais, planícies fluviomarinhas, áreas de dunas, cordões litorâneos retrabalhados em superfície pelo vento e áreas sujeitas à erosão marinha sejam ocupados.

O uso de Cartas Geomorfológicas de Detalhe é um importante documento para a preparação do Plano Diretor Municipal, ainda não implantado para o município de llha Comprida. Tais documentos poderiam contribuir e fornecer dados para a determinação de possíveis zonas de expansão urbana e zonas de proteção às características naturais da área de estudo.

\section{REFERÊNCIAS}

AB'SABER, A. N. Fundamentos de geomorfologia costeira do Brasil atlântico inter e subtropical. Revista Brasileira de Geomorfologia, Uberlândia: UFU, v.1, n.1, p. 2743, 2000.

ALMEIDA, F. F. M. Fundamentos geológicos do relevo paulista. São Paulo: Universidade de São Paulo, 1964.

CASSETI, V. Ambiente e apropriação do relevo. São Paulo: Contexto, 1991.

CHRISTOFOLETTI, A. Modelagem de sistemas ambientais. São Paulo: Blucher, 1999.

COELHO, M. R.; MARTINS, V. M.; VIDAL-TORRADO, P.; SOUZA, C. R. G.; PEREZ, X. L. O.; VÁZQUEZ, F. M. Relação solo-relevo-substrato geológico nas restingas da planície costeira do estado de São Paulo. Revista Brasileira de Ciência do Solo, Campinas, v. 34, p.833-846, 2010.

CUNHA, C. M. L.; MENDES, I. A.; SANCHEZ, M. C. A Cartografia do relevo: uma análise comparativa de técnicas para a gestão ambiental. Revista Brasileira de Geomorfologia, Goiânia, ano 4, n. 1, p.01-09, 2003.

GIANNINI, P. C. F.; GUEDES, C. C. F.; NASCIMENTO JUNIOR, D. R.; TANAKA, A. P. B.; ANGULO, R. J.; ASSINE, M. L.; SOUZA, M. C. Sedimentology and morphological evolution if the Ilha Comprida barrier system, Southern São Paulo 
coast. In: DILLENGURG, S. R.; HESP, P. A. (Org.). Geology and geomorphology of Holocene coastal barriers of Brazil. Berlin: Springer-Verlag Berlin Heidelberg, 2009. 06, p.177-224.

GIRÃO, O.; CORRÊA, A. C. B. A contribuição da geomorfologia para o planejamento da ocupação de novas áreas. Revista de Geografia, Recife, v. 21, n. 2, p. 36-58, 2004.

GUEDES, C. C. F. Evolução sedimentar quaternária da Ilha Comprida, estado de São Paulo. 2009. Dissertação (Mestrado em Geoquímica e Geotectônica) Instituto de Geociências, Universidade de São Paulo, São Paulo.

GUERRA, A. J. T.; MARÇAL, M. S. Geomorfologia ambiental. Rio de Janeiro: Bertrand Brasil, 2006.

HENRIQUE, W.; MENDES, I. A. Areias em movimento - um estudo sobre a morfodinâmica da Ilha Comprida - SP. Geografia, Rio Claro, v.24, n.3, p.69-92, 1999.

INSTITUTO BRASILEIRO DE GEOGRAFIA E ESTATÍSTICA (IBGE). Cidades@. Disponível em: <http://www.ibge.gov.br/cidadesat/topwindow.htm?1>. Acesso em: 10 set. 2014.

INSTITUTO BRASILEIRO DE GEOGRAFIA E ESTATÍSTICA (IBGE). Manual Técnico de Geomorfologia. Rio de Janeiro: IBGE, 2009, 2ª Edição.

LIMA, C. O. Compartimentação geomorfológica para o município de llha Comprida - SP. 2011. Monografia (Graduação em Geografia) - Instituto de Geociências, Universidade Estadual de Campinas, Campinas.

MARETTI, C. C.; FILET, M. Ilha Comprida: um desafio ao planejamento ambiental. Ambiente - Revista CETESB de Tecnologia, São Paulo, v.2, n.2, p.66-73, 1988.

MARTIN, L.; SUGUIO, K. Ilha Comprida: um exemplo de ilha-barreira ligado às flutuações do nível marinho durante o Quaternário. In: CONGRESSO BRASILEIRO DE GEOLOGIA, 30, 1978, Recife: Sociedade Brasileira de Geologia, 1978, p.905912.

NASCIMENTO JUNIOR, D. R.; GIANNINI, P. C. F.; TANAKA, A. P. B.; GUEDES, C. C. F. Mudanças morfológicas da extremidade NE da llha Comprida (SP) nos últimos dois séculos. Geologia USP: Série Científica, São Paulo, v.8, n.1, p.25-39, 2008. 
OLIVEIRA, R. C.; DIAS, R. L. O estudo das unidades de relevo em regiões litorâneas: o exemplo do litoral sul do estado de São Paulo. Caminhos de Geografia, Uberlândia, v. 13, n. 41, p. 122-145, 2012.

RITCHOT, G. La Cartographie en noir et blanc. Cahiers de Géographie du Québec, Québec, v.14, n.33, p.359-376.

SADOWSKY, V. Observações sobre as modificações em curso na entrada de Cananéia, de sua barra e da região adjacente - I. Desgaste das costas. №. 1 Ponta da Trincheira (1952). Boletim do Instituto Oceanográfico, São Paulo, v.3, n.1-2, 1952.

SPINELLI, F. P.; GOMES, C. B. A ocorrência alcalina de Cananeia, litoral sul do estado de São Paulo: geologia e geocronologia. Geologia USP: Série científica, São Paulo, v.8, n. 2, p.53-64, 2008.

SOUZA, T. A.; OLIVEIRA, R. C. A cartografia geomorfológica de detalhe aplicada ao litoral Sul do estado de São Paulo: a llha Comprida como estudo de caso. In: SIMPÓSIO NACIONAL DE GEOMORFOLOGIA, 9, 2012, Rio de Janeiro: UFRJ, 2012a, p.01-04.

SOUZA, T. A.; OLIVEIRA, R. C. Avaliação da potencialidade de imagens tridimensionais em meio digital para o mapeamento geomorfológico. Revista Geonorte, Manaus, v.2, n.4, p.1348-1355, 2012b.

TESSLER, M. G.; SUGUIO, K.; MAHIQUES, M. M.; FURTADO, V. V. Evolução temporal e espacial da desembocadura lagunar de Cananeia (SP). Boletim do Instituto Oceanográfico, São Paulo, v.38, n.1, p.23-29, 1990.

TRICART, J. Principes et méthodes de la géomorphologie. Paris: Masson, 1965.

VERSTAPPEN, H. T.; VAN ZUIDAM, R. A. ITC System of geomorphological survey. Enschede: ITC, 1975. 